\title{
Analysis of feeding of Sardina pilchardus (Walbaum, 1792) larval stages in the central Cantabrian Sea
}

\author{
ITZIAR MUNUERA FERNÁNDEZ ${ }^{1}$ and RAFAEL GONZÁLEZ-QUIRÓS ${ }^{2}$ \\ ${ }^{1}$ Departamento de Biología de Organismos y Sistemas, Unidad de Ecología, Universidad de Oviedo, C/ Catedrático \\ Rodrigo Uría s/n, E-33006 Oviedo, Spain. E-mail: imunuera.uo@uniovi.es \\ ${ }^{2}$ CIFAP El Toruño, IFAPA, Carretera N-IV km 654, 11500 El Puerto de Santa María, Cádiz, Spain.
}

\begin{abstract}
SUMMARY: Diet analysis of larval fish may clarify the role that zooplankton - not only its abundance but also its size structure and taxonomic composition - may have on larval growth and subsequent recruitment levels. Taking into account the increase in size during larval stages, we followed a larval size-dependent approach for the analysis of prey size in the diet of larval sardine (Sardina pilchardus). Studies on feeding patterns of clupeid larvae typically involve a problem due to regurgitation and defecation of gut contents during capture. Therefore, an alternative sampling method was tested in this study, but no significant differences from conventional methods were found. Despite the low feeding incidence observed (23\%), we found a circadian feeding pattern with the highest mean gut contents after dawn, decreasing during the day and with the lowest values at night. Diet was mostly composed of copepod developmental stages, mainly nauplii, and prey size increased with larval size following a power function. Maximum and mean prey size were related to larval mouth gape, though other factors may be restricting the maximum prey size ingested, since most prey width values were between 20 and $40 \%$ of larval mandible width.
\end{abstract}

Keywords: larval diet, Sardina pilchardus, circadian feeding pattern, Cantabrian Sea.

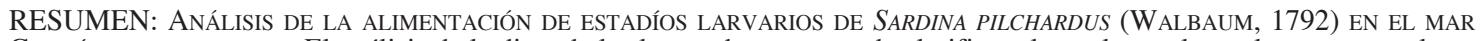
CANTÁBRICO CENTRAL. - El análisis de la dieta de las larvas de peces puede clarificar el papel que el zooplancton, no solo su abundancia sino también su estructura de tamaños y su composición taxonómica, pueden tener en el crecimiento larvario y los subsecuentes niveles de reclutamiento. Teniendo en cuenta el incremento de tamaño durante los estadíos larvarios, hemos seguido una aproximación dependiente del tamaño para el análisis del tamaño de presa en la dieta de larvas de sardina (Sardina pilchardus). Los estudios sobre los patrones de alimentación de las larvas de clupeidos suelen presentar problemas debido a la regurgitación y defecación de los contenidos digestivos durante la captura. En este sentido, en el presente estudio se probó un nuevo método de muestreo pero no se encontraron diferencias significativas respecto a los métodos convencionales. A pesar de la baja incidencia alimenticia observada (23\%), encontramos un patrón alimenticio circadiano con valores medios de contenidos digestivos más elevados después del amanecer, que decrecen durante el día y se minimizan por la noche. La dieta se compuso fundamentalmente de estadíos de desarrollo de copépodo, sobre todo nauplii, y el tamaño de presa aumentó con el tamaño de larva siguiendo una función potencial. El tamaño máximo y medio de presa se relacionó con la apertura bucal de las larvas, aunque otros factores pueden restringir el tamaño máximo de presa ingerida, ya que el tamaño de la mayoría de las presas se encontró entre el $20 \%$ y el $40 \%$ de la anchura de mandíbula larvaria.

Palabras clave: dieta larvaria, Sardina pilchardus, patrón de alimentación circadiano, mar Cantábrico.

\section{INTRODUCTION}

Food availability is considered to be one of the main factors affecting the growth rate of pelagic fish larvae (Hjort, 1914). The match/mismatch hypothe- sis (Cushing, 1975) argues that recruitment variability in pelagic fish populations is caused by massive mortality of larval stages under low food availability conditions. Houde (1987) demonstrated that small changes in growth and mortality rates may 
cause high variability in the magnitude of recruitment. Precise characterisation of larval diet is needed in order to understand which particular food availability conditions may cause growth variability. Specifically, there is a need for an adequate sizedependent analysis of feeding patterns, taking into account the increase in size during larval stages (Houde, 1987) and the fact that their diet is mostly composed of copepod developmental stages in most fish species (Last, 1980). Mouth gape has been proposed as the chief morphological constraint to maximum prey size ingested (Shirota, 1970). In addition, Pearre (1986) recommended an analysis based on a log transformation of larval and prey size, since prey size variance usually increases with larval size (Conway et al., 1994; Llanos et al., 1996; Pepin and Penney, 1997) and available prey biomass for a predator, on average, remains constant in the ocean within equal logarithmic intervals of particle diameter (Sheldon et al., 1972).

Circadian feeding patterns have been previously reported for larval sardine (Conway et al., 1994) and other fish species (Conway, 1980). This pattern must be taken into account for the analysis of gut contents from larvae collected at different locations, since dissimilarities in feeding incidence and amount of prey within the gut may be due to diel feeding behaviour instead of variations in food availability between sampling sites.

The Iberian stock of sardine (Sardina pilchardus, Walbaum), which supports an important fishery, has decreased during the last few years, which has been associated with successive years of low recruitment (Porteiro and Pestana, 1997). The Cantabrian Sea is known to be an important spawning ground for sardine, high density of eggs and larvae occurring from March to May.

Fish larvae with long and thin stomachs (i.e. sardine larvae) usually have a low feeding incidence, suggesting that current ichthyoplankton sampling methods provoke gut content loss due to stress during trawls. An alternative sampling method was tested in this study in an attempt to minimise larval stress.

The objective of our study was to analyse some characteristics of Sardina pilchardus larval diet in the Cantabrian Sea, namely to determine circadian feeding patterns, number of prey in the gut and feeding incidence, and type and size of consumed prey, taking into account the increase in size during the larval period. Secondarily, we tested the efficiency of an alternative sampling technique for larval stages with elongated stomachs.

\section{MATERIALS AND METHODS}

Sampling was carried out at four stations during a daily cycle (every four hours, for 24 hours) during an intensive oceanographic survey (SARDINA) on the central Cantabrian shelf slope in May 2000 (Fig. 1). Station 1 was sampled on May 14 and 15, station 2 on May 16 and 17, station 3 on May 17 and 18, and station 4 on May 8 and 9. Two different methods were used to sample larvae for gut content analysis:

(1) vertical trawls with an RF net (1 m diameter and $200 \mu \mathrm{m}$ mesh) with a transparent $301 \mathrm{cod}$ end without filtrating window. Tow depth was to $50 \mathrm{~m}$ and upward velocity $0.5 \mathrm{~m} \mathrm{~s}^{-1}$. On board, larvae were pipetted from the cod end and immediately preserved in a $4 \%$ formalin seawater solution.

(2) Double-oblique trawls with a bongo net (60 $\mathrm{cm}$ diameter and $200 \mu \mathrm{m}$ mesh) and vessel velocity at $1 \mathrm{~m} \mathrm{~s}^{-1}$, maximum net depth being $5 \mathrm{~m}$ off the bottom. On board, plankton samples including sardine larvae were preserved in a $4 \%$ formalin seawater solution.

In total, 618 larvae were examined, and 10 to 40 larvae from each sampling time were analysed at each station. Standard length (SL) and mandible width (MW) and length (ML) were measured to the nearest $0.01 \mathrm{~mm}$. MW was preferred instead of mouth gape, since width can be measured with greater accuracy. Their digestive tracts were dissected with a needle and the gut contents were counted, identified and measured. Feeding incidence was cal-

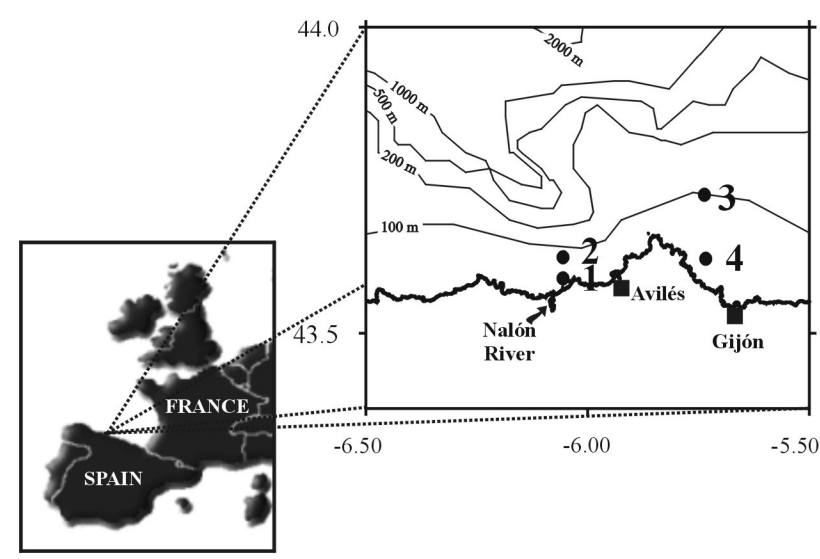

FIG. 1. - Area of study. 
culated as the proportion of larvae with at least one prey in the gut. There were five identified prey types: tintinnids, copepod eggs, copepod nauplii, copepod copepodites and other prey (faecal pellets, other eggs and radiolarians). Prey length (PL) and width (PW) were measured to the nearest $0.001 \mathrm{~mm}$. Prey width (PW) was measured as egg diameter, maximum cephalothorax width for copepod nauplii and copepodites and maximum width for tintinnids and faecal pellets.

PW and larval SL were log transformed following recommendation from Pearre (1986). Prey and larvae were divided into size classes with equivalent logarithmic scale range, larval SL classes being 4.57.6, 7.7-13 and 13.1-22.1 mm, and PW classes 2554, 55-116 and $117-250 \mu \mathrm{m}$.

Microplankton $>53 \mu \mathrm{m}$ was sampled with a $10 \mathrm{~cm}$ diameter bongo net with $53 \mu \mathrm{m}$ mesh attached above the largest bongo net. Samples were preserved in a $4 \%$ formalin seawater solution. At each sampling time within a daily cycle, prey abundance was estimated from 0.0033 or 0.0025 of the sample volume, and prey abundance for each station was estimated from the mean abundance at the different sampling times during each daily cycle. Several prey types were identified (see above) and their length and width were measured to the nearest $0.001 \mathrm{~mm}$ under an inverted microscope. If necessary, an extra subsample was taken in order to measure up to 50 copepod nauplii and copepodites to estimate prey size class distribution.
We used general linear modelling (GLM) to analyse the differences in the number of prey per larva between sampling times within a daily cycle and between stations. GLM allows a versatile analysis of correlation, as the error distribution of the dependent variable and the function linking predictors to it can be adjusted to the characteristics of the data (Figuerola et al., 2002). For this analysis we used a Poisson error model with a log link function. Poisson errors are widely used for the analysis of count data, and as the model followed by our data is not overdispersed (Crawley 1993) we considered the Poisson as the most suitable error structure.

We considered station (S) and sampling time (T) as independent factors for the GLM analysis, taking four levels for $\mathrm{S}$ and five levels for $\mathrm{T}$ since sampling times were different for each $\mathrm{S}$. Thus, we made the following time ranges including comparable levels of T: for time 1, 19:00-23:00 UTC; for time 2, 23:00-3:00 UTC; for time 3, 3:00-7:00 UTC; for time 4, 7:00-11:00 UTC; and for time 5, 11:00-15:00 UTC. T between 15:0019:00 UTC were not included in the analysis because not all the $\mathrm{S}$ had a $\mathrm{T}$ within that range.

\section{RESULTS}

\section{Bongo vs. RF}

No significant differences were found in feeding incidence between larvae sampled with bongo and

TABLE 1. - Abundance (individuals $\mathrm{m}^{-3}$ ) of prey types and sizes in the plankton (only the prey types and prey sizes that were observed within the gut contents). (Ap. faecal pellets = appendicularian faecal pellets).

\begin{tabular}{|c|c|c|c|c|c|c|c|c|}
\hline \multirow[t]{2}{*}{ Station } & \multirow[t]{2}{*}{$\begin{array}{l}\text { Prey Width } \\
(\mu \mathrm{m})\end{array}$} & \multicolumn{7}{|c|}{ Copepod Developmental Stages } \\
\hline & & Eggs & Nauplii & Copepodites & Ap. faecal pellets & Tintinnids & Other eggs & Total \\
\hline 1 & $\begin{array}{l}25-54 \\
55-116 \\
117-250 \\
\text { Total }\end{array}$ & $\begin{array}{l}\overline{706} \\
\overline{706}\end{array}$ & $\begin{array}{c}925 \\
3383 \\
70 \\
4378\end{array}$ & $\begin{array}{c}\overline{153} \\
1318 \\
1471\end{array}$ & $\begin{array}{c}466 \\
388 \\
167 \\
1021\end{array}$ & $\begin{array}{l}\overline{26} \\
\overline{26}\end{array}$ & $\begin{array}{l}- \\
\overline{143} \\
143\end{array}$ & $\begin{array}{l}1391 \\
4656 \\
1699 \\
7746\end{array}$ \\
\hline 2 & $\begin{array}{l}25-54 \\
55-116 \\
117-250 \\
\text { Total }\end{array}$ & $\begin{array}{l}33 \\
610 \\
\overline{643}\end{array}$ & $\begin{array}{c}357 \\
2666 \\
91 \\
3114\end{array}$ & $\begin{array}{c}\overline{34} \\
1007 \\
1042\end{array}$ & $\begin{array}{l}236 \\
549 \\
\overline{785}\end{array}$ & $\begin{array}{l}\overline{95} \\
\overline{95}\end{array}$ & $\begin{array}{l}- \\
\overline{74} \\
74\end{array}$ & $\begin{array}{c}626 \\
3955 \\
1172 \\
5753\end{array}$ \\
\hline 3 & $\begin{array}{l}25-54 \\
55-116 \\
117-250 \\
\text { Total }\end{array}$ & $\begin{array}{c}41 \\
474 \\
33 \\
549\end{array}$ & $\begin{array}{c}184 \\
2535 \\
80 \\
2799\end{array}$ & $\begin{array}{l}- \\
\overline{1058} \\
1058\end{array}$ & $\begin{array}{c}65 \\
168 \\
43 \\
275\end{array}$ & $\begin{array}{c}10 \\
69 \\
41 \\
121\end{array}$ & $\begin{array}{l}- \\
\overline{111} \\
111\end{array}$ & $\begin{array}{c}300 \\
3247 \\
1365 \\
4913\end{array}$ \\
\hline 4 & $\begin{array}{l}25-54 \\
55-116 \\
117-250 \\
\text { Total }\end{array}$ & $\begin{array}{l}1 \overline{66} 4 \\
1 \overline{66} 4\end{array}$ & $\begin{array}{c}202 \\
2521 \\
2 \overline{72} 3\end{array}$ & $\begin{array}{c}\overline{605} \\
454 \\
1059\end{array}$ & $\begin{array}{l}101 \\
454 \\
101 \\
655\end{array}$ & - & $\begin{array}{l}- \\
\overline{202} \\
202\end{array}$ & $\begin{array}{c}303 \\
5244 \\
504 \\
6050\end{array}$ \\
\hline
\end{tabular}


RF nets $\left(\chi_{1,0.05}^{2}=2.737 ; \mathrm{p}>0.05\right)$. As larvae $>13 \mathrm{~mm}$ SL were not abundant in RF samples, larvae 13.1$22.1 \mathrm{~mm}$ SL obtained from bongo net samples were included in the subsequent diet analysis.

\section{Composition and abundance of potential prey in the plankton}

Total abundance of potential prey was similar at the 4 stations. Prey between 55-116 $\mu$ m were the most abundant, with the maximum number of individuals per $\mathrm{m}^{3}$ at station 4 and the minimum at station 3. Copepod nauplii dominated microplankton of 25-116 $\mu \mathrm{m}$ (Table 1), while copepodites were the most abundant prey type within the 117-250 $\mu \mathrm{m}$ PW class. We included the 25-54 $\mu \mathrm{m}$ PW class since prey $<54 \mu \mathrm{m}$ were present in the larval gut contents. However, this size class was not adequately sampled by the $54 \mu \mathrm{m}$ mesh of the small bongo net.
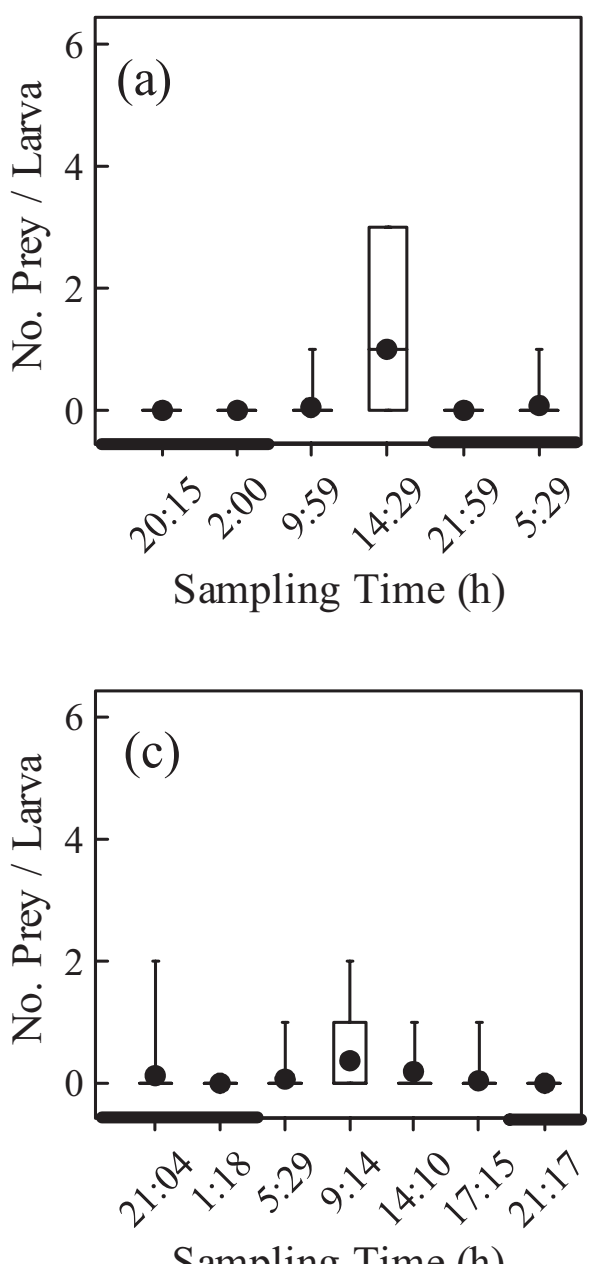

Sampling Time (h)

\section{Circadian feeding patterns}

Larvae had higher mean gut contents just after dawn, decreasing during the day and showing lowest values at night (Fig. 2). There was a significant interaction between $\mathrm{T}$ and $\mathrm{S}$, i.e. number of prey per larva differed between sampling times depending on the station the larvae came from (Table 2). Station 1, which is affected by the River Nalon plume (Fig. 1), differed from the general pattern described above in that the maximum mean number of prey per larva was found at 14:30 UTC, not just after dawn. At Station 2, the maximum number of prey per larva was observed at 12:40 UTC, partially due to a larva with six nauplii within its gut at this sampling time. Excluding this larva, the maximum value would appear at 7:45 UTC. Station 4 showed the highest values and station 3 the lowest values of number of prey per larva at almost all the sampling times (Fig.
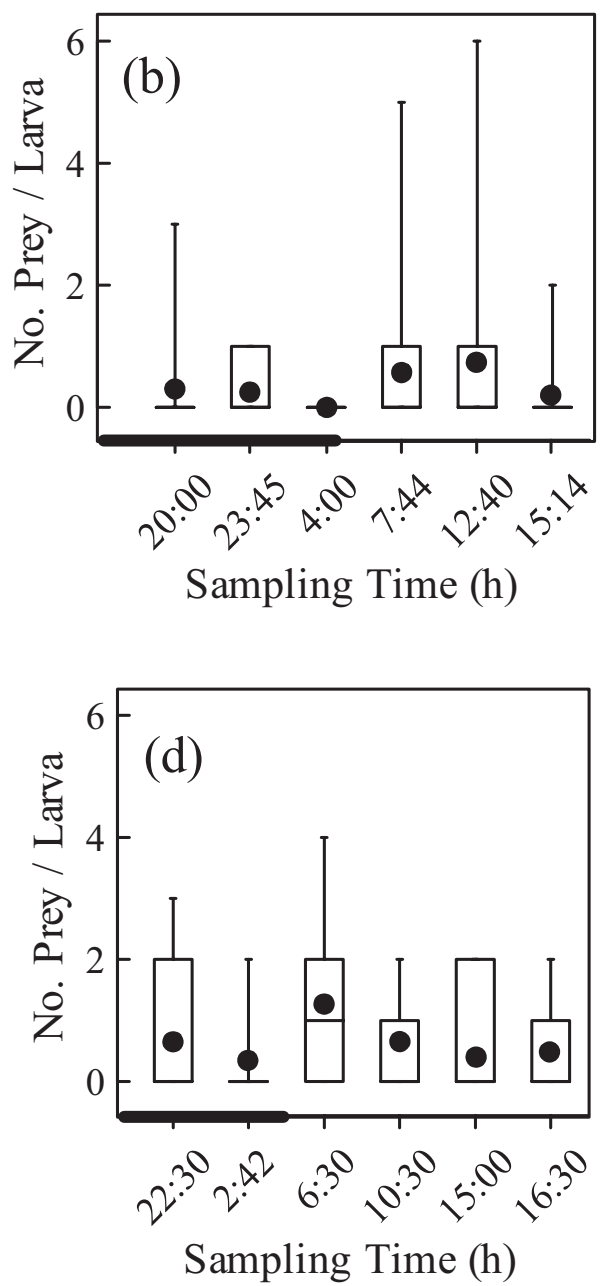

FIG. 2. - Circadian feeding pattern: box-whisker plot (median, quartiles and extremes) and mean number of prey per larva (black dots). Data from station 1 (a); station 2 (b); station 3 (c); station 4 (d). 
TABLE 2. - Results of the general linear model analysis including degrees of freedom (d.f.), $F$ and p values.

\begin{tabular}{lcccc}
\hline Source of Variation & d.f. & Scaled Deviance & $F$ & $\mathrm{p}$ \\
\hline Station & 3 & 41.57 & 13.86 & 0.014 \\
Time & 4 & 10.17 & 2.54 & 0.094 \\
Station x Time & 12 & 82.82 & 6.90 & 0.000 \\
Error & 326 & - & - & - \\
Total & 345 & - & - & - \\
\hline
\end{tabular}

3), coinciding with the maximum and minimum abundance of prey between 55-116 $\mu \mathrm{m}$ width respectively (Table 1).

\section{Feeding incidence and number of prey}

The size range of analysed larvae was between 4.5 and $22.1 \mathrm{~mm}$ in length. Feeding incidence was low for the three larval SL classes: $26.2 \%$ for class $1,20.3 \%$ for class 2 and $15.0 \%$ for class 3 . Only $23 \%$ out of 618 analysed larvae contained preys in their guts. Most larvae with gut contents had only 1
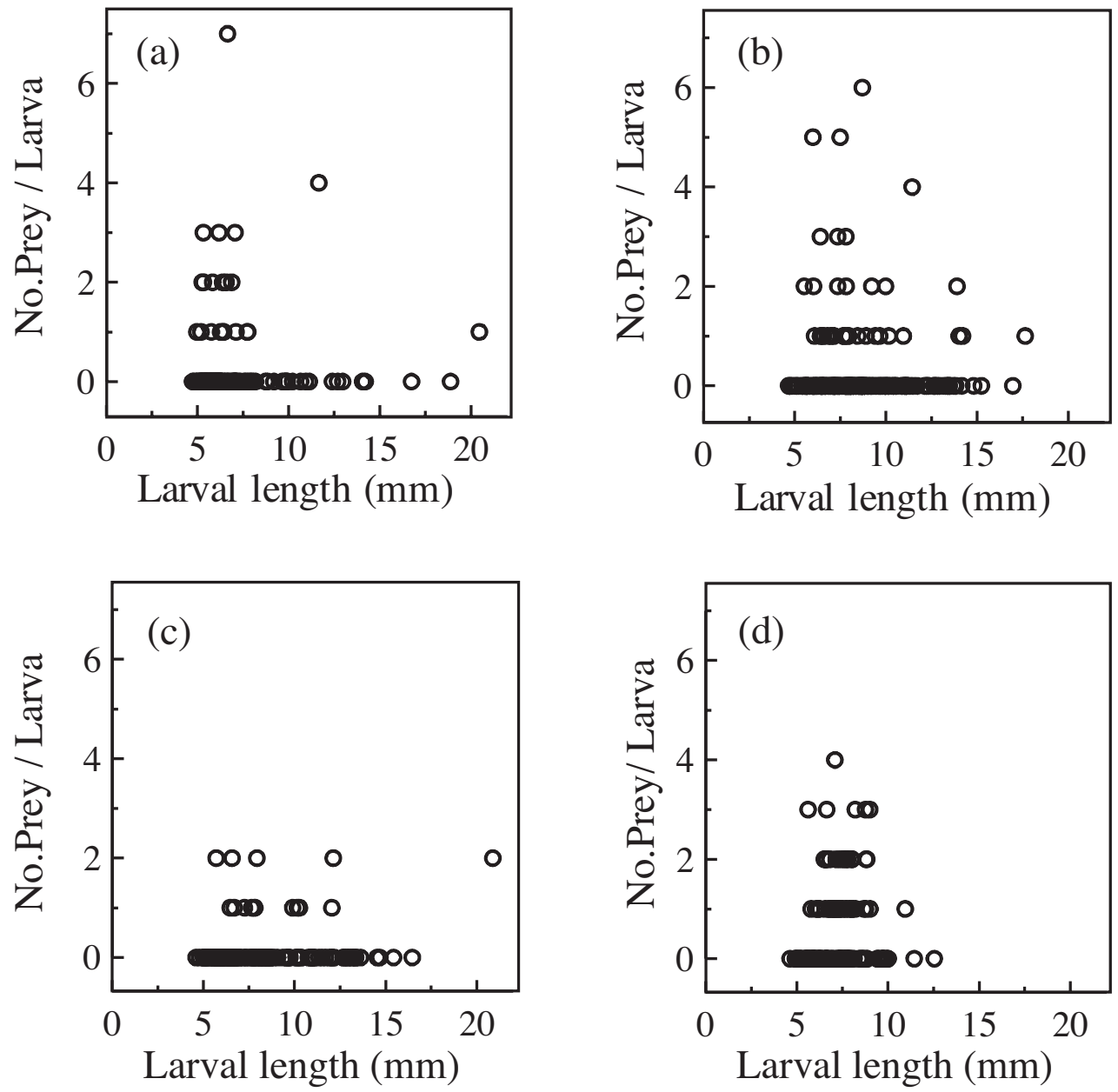

FIG. 4. - Number of prey per larva in relation to larval SL in (a) station 1, (b) station 2, (c) station 3 and (d) station 4. 
TABLE 3. - Regression lines fitted by a linear equation. Mandible Length (ML, mm), Mandible Width (MW, $\mathrm{mm}$ ) and larval Standard Length (SL, mm) data). $n=$ number of larvae analysed in each case. All $\mathrm{F}$ values were significant at $\alpha<0.0001$.

\begin{tabular}{llcc}
\hline$n$ & Linear regression equation & $r^{2}$ & $\mathrm{~F}$ \\
\hline 474 & MW $=0.031 \mathrm{SL}+0.143$ & 0.74 & 1344.99 \\
421 & ML $=0.058 \mathrm{SL}+0.044$ & 0.85 & 2284.25 \\
409 & MW $=0.458 \mathrm{ML}+0.162$ & 0.71 & 991.30 \\
\hline
\end{tabular}

prey in their gut (60.6\%) and up to a maximum of 7 preys per larva were observed (Fig. 4). There was no clear relationship between number of prey per larva and larval SL at any of the 4 stations.

\section{Prey type}

Diet was mostly composed of copepod developmental stages (Fig. 5), which represented $93.7 \%$ of all prey items. Nauplii represented $51.7 \%$, copepodites $36.7 \%$ and copepod eggs $5.3 \%$ of total prey. Also found were tintinnids, other prey types (other eggs, faecal pellets and radiolarians) and unidentified

\section{Diet composition}
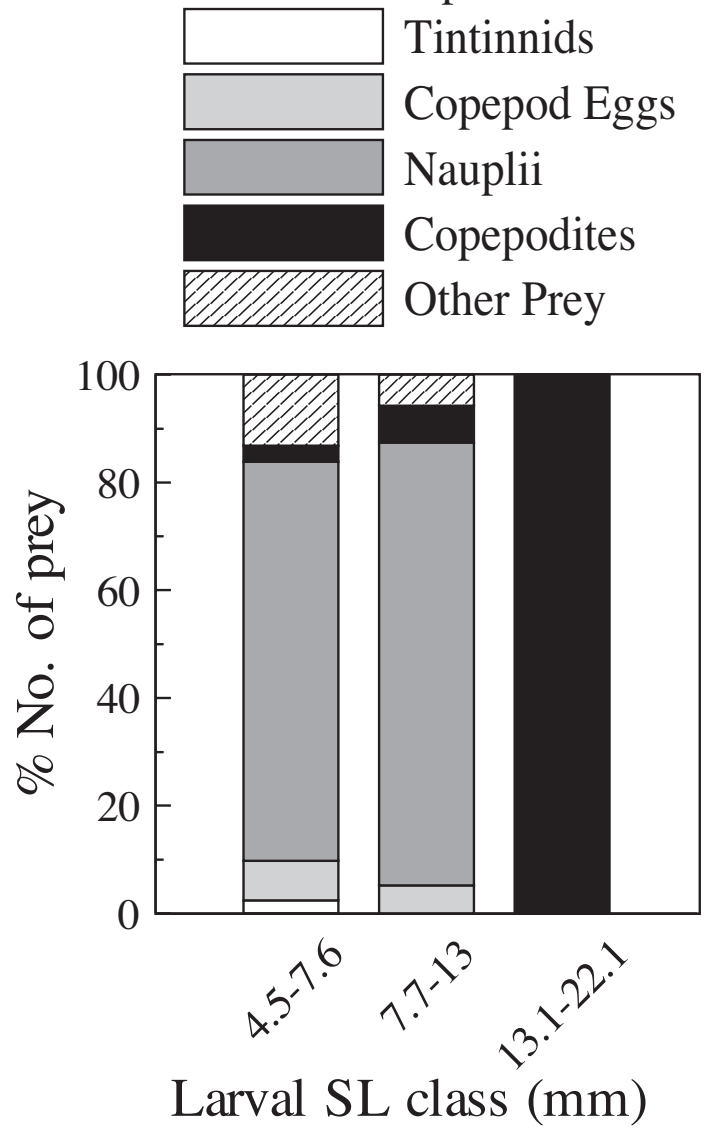

FIG. 5. - Percentage of the different prey types in the guts of sardine larval SL classes.

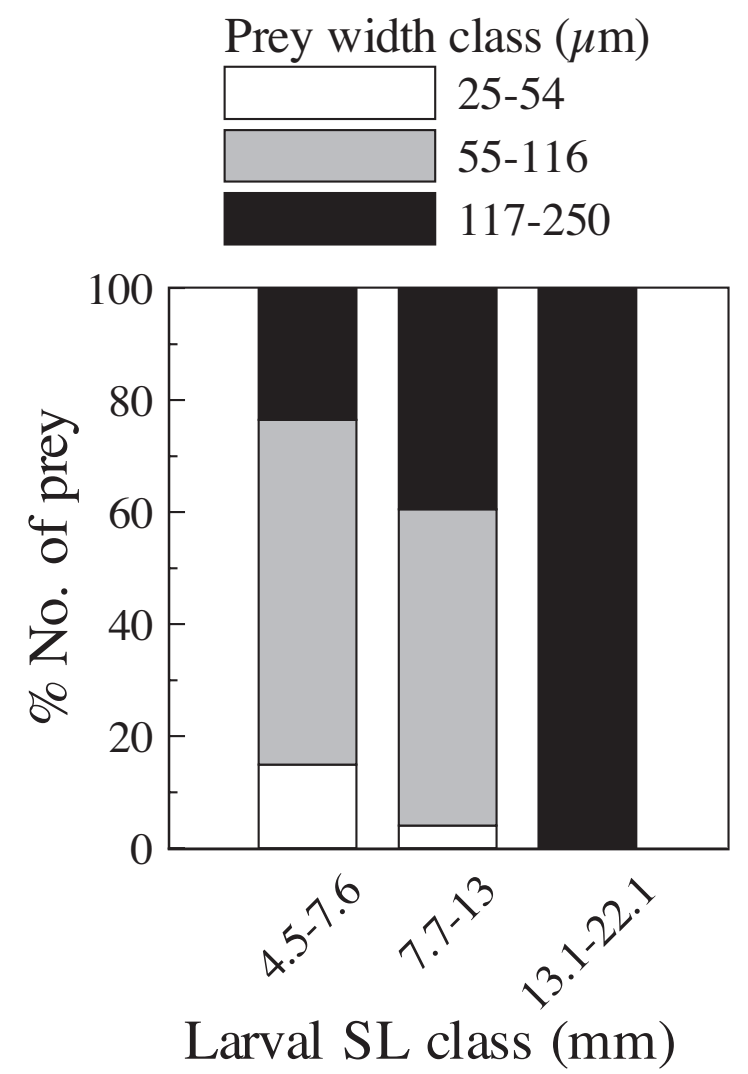

FIG. 6. - Percentage of the different prey width classes in the guts of sardine larval SL classes.

particles. A shift from nauplii to copepodites was observed from the 7.7-13 $\mathrm{mm}$ to the $13.1-22.1 \mathrm{~mm}$ larval class.

\section{Prey size}

Prey size increased with larval SL. The smallest PW class (25-54 $\mu \mathrm{m})$ represented only a small percentage of the diet in the $4.5-13 \mathrm{~mm}$ larval SL class, and it was absent in gut contents of large larvae (Fig. 6).

MW against larval SL showed higher variance in smaller larvae (Fig. 7). This may be, at least partially, a consequence of a higher measurement error in small larvae, for which the mandible is less apparent. Therefore, larval SL instead of MW was used to calculate regressions against PW. Maximum and mean $\log$ PW against larval SL followed a power function (Fig. 7; Table 4) that seemed to be related to the morphometric relationship between MW and SL. However, $80 \%$ of maximum PW are comprised between regression lines representing 20 and $40 \%$ of $\mathrm{MW}$ and there is no value above that corresponding to $60 \%$. 
TABLE 4. - Results of the regression analysis between logarithms of SL (mm) and of maximum prey width (Max PW, mm) and between the logarithms of SL $(\mathrm{mm})$ and mean prey width (mean PW, mm). $n=$ number of larvae analysed in each case. All $F$ values were significant at $\alpha<0.0001$. The correspondent equivalent power equations are also presented.

\begin{tabular}{|c|c|c|c|c|}
\hline$n$ & Linear regression equation & $r^{2}$ & $F$ & Power regression equation \\
\hline $\begin{array}{l}101 \\
101\end{array}$ & $\begin{array}{l}\log _{10}(\text { Max PW })=0.96 \log _{10}(\mathrm{SL})-1.83 \\
\log _{10}(\text { mean PW })=0.92 \log _{10}(\mathrm{SL})-1.81\end{array}$ & $\begin{array}{l}0.39 \\
0.38\end{array}$ & $\begin{array}{l}64.66 \\
62.26\end{array}$ & $\begin{array}{l}\text { Max PW }=0.015 \mathrm{SL}^{0.96} \\
\text { mean PW }=0.016 \mathrm{SL}^{0.92}\end{array}$ \\
\hline
\end{tabular}

(a)

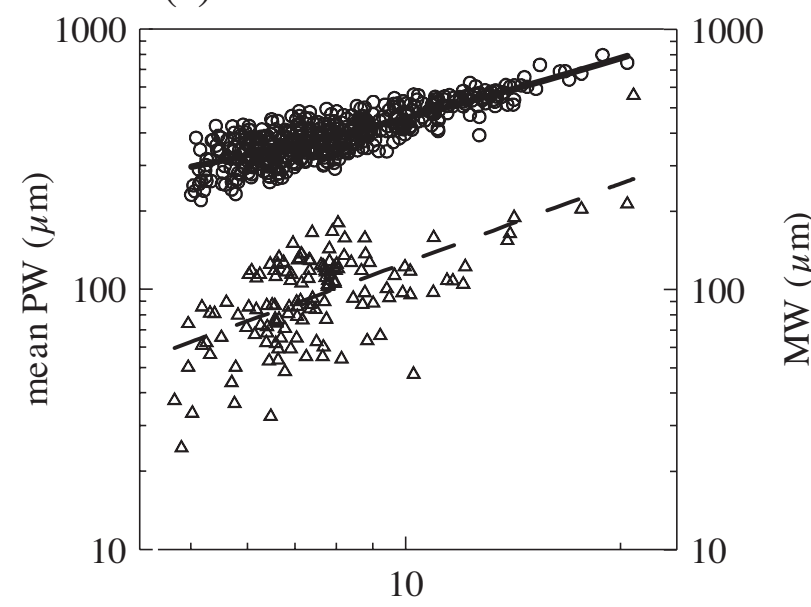

Larval SL (mm) (b)

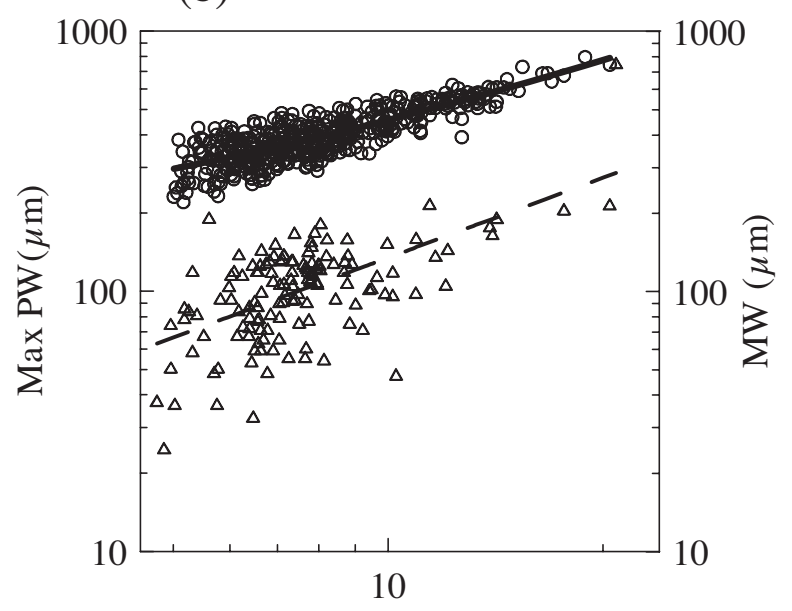

Larval SL (mm)

FIG. 7. - (a) Mean prey width (Wm, $\mu \mathrm{m}$, triangles) and mandible width (MW, $\mu \mathrm{m}$, dots) against larval SL (mm). (b) Maximum prey width (WM, $\mu \mathrm{m}$, circles) and mandible width ( $\mu \mathrm{m}$, dots) against larval SL (mm). (Note logarithmic scales). Regression lines fitted by a power function: Wm and WM against larval SL (continous line); regression line fitted by a linear function: MW against larval SL (dashed line).

\section{DISCUSSION}

The tendency of clupeids to evacuate food in response to the trauma of conventional sampling is well documented (Hay, 1981). The low feeding incidence of sardine larvae in this study was similar to previously reported values for sardine (Conway et al., 1991, 1994) and other larval fish with straight intestinal tracts (Dekhnik, 1974), and higher than the values presented by Tudela $e t$ al. (2002) for larval anchovy. The utilisation of a vertical tow and a large cod end without filtrating window was an attempt to reduce turbulence within the cod end during the tow, which may cause stress to sardine larvae. Once the 301 cod-end was on board we observed that some of the larvae were still alive. However, they soon died, excluding the possibility that stress caused by formalin fixation was the cause of gut content loss. It seems that turbulence within the 301 bucket was still too high to prevent gut content loss. Lower haul upward velocity might have prevented this effect to some extent. Still, it would have increased net avoidance by sardine larvae and consequently reduced the number of caught larvae. Number of prey within the gut may have been underestimated in our study due to gut content loss. Moreover, the absence of an increase in number of prey with larval size must be questioned, although it has been observed in other species (González-Quirós and Anadón, 2001). Still, a qualitative analysis of sardine larval diet can be reliable, since it does not seem reasonable that food evacuation mediated by stress depends on prey type, prey size or even time during a circadian cycle.

A slight error in diet analysis could have been introduced in the present study by using larvae from two types of net, though there were no significant differences either in food quantity or in feeding incidence between larvae collected with the two methods, and apparently introducing larvae between 13.1-22.1 mm SL collected with a bongo net does not make a difference in tendency for regressions calculated with larval and prey size.

Our analysis of circadian variability in gut contents showed the highest feeding incidence and 
mean gut contents early in the morning. The highest mean number of prey per larva at almost all the sampling times was found at station 4 , which could be related to the fact that the abundance of potential prey of medium size $(55-116 \mu \mathrm{m})$, those most consumed by larvae between 7.7-13 $\mathrm{mm}$ SL (Fig. 6), reached the highest values at that station. In addition, the lowest values were found at station 3, with the lowest abundance of prey between 55-116 $\mu \mathrm{m}$ width.

Conway et al. (1994) found a diel feeding pattern for sardine larvae in the Cantabrian Sea with maximum feeding incidence between 8:00 and 10:00 h, which is similar to the pattern observed in our study. On the other hand, Conway et al. (1991) did not find a clear pattern for different larval size classes and none of them showed the pattern referred to above. Both the latter studies were based on larvae sampled at different locations and dates during an extensive cruise, so their results could be a consequence of differences in food availability between locations. Taking into account the circadian feeding variability, despite the low number of stations and the reported loss of gut contents our data suggest a relationship between prey availability in the environment and number of prey per larva within the gut.

Copepod developmental stages composed the majority of the diet in larvae analysed in this study. This is the case of larval stages of most pelagic fish (Last, 1980) and has also been observed previously in sardine larvae (Conway et al., 1994). Conway et al. (1994) found a gradual increase in the consumption of copepodites for sardine larvae in the Cantabrian Sea. In contrast, our results showed a sudden increase in the consumption of this type of prey in large larvae, while the small ones did not consume copepodites. This difference may be a consequence of different prey type abundance and size structure in the plankton. However, prey size structure was not analysed in the referred study. It is worth noting that radiolarians around $160 \mu \mathrm{m}$ diameter were found in the gut of several larvae (included in other prey), which have not been noted by other authors.

In this study, maximum prey size within the guts seems to be related to mouth gape, although high dispersion of the data was observed. However, $71 \%$ of total gut contents were between 20 and $40 \%$ of larval MW, these values being similar to the ones found by Llanos et al. (1996) in four species of clupeids. Munk
(1997) concluded that for prey sizes over the size of maximum preference, the rate of decrease of catchability, which is influenced by prey avoidance and escape, overrides the rate of increase in visibility. Even though maximum prey size has a similar relationship as mandible size to larval SL, other related constraints, such as relative mobility of larval sardine and their prey and size dependent catchability, may restrict the maximum prey size ingested.

Fish larvae increase their biomass by a factor of $\mathrm{x} 10^{3}$ in a relatively brief period (Houde, 1987). Energetic demands for maintenance of this high growth rate must change dramatically as a consequence of size. Despite the absence of an increase in number of prey ingested with larval size, which may be to some extent a consequence of gut content loss mediated by stress, the patterns observed in number of prey and prey size suggest that the energetic demand would be achieved by the observed increase in prey size. Prey availability and its influence on larval growth rate must be analysed in view of the larval size-dependent changes observed in prey size ingested.

\section{ACKNOWLEDGEMENTS}

We are thankful to the crew of the R/V García del Cid for their work during the survey. We are also grateful to all the members of the B.O.S. Department (Ecology Area) who were involved in sampling procedures for their enthusiastic and generous help during the cruise. This study was funded by the CICYT (Spanish Government) project 1FD97-1045-C02-01 under the FEDER programme. I. Munuera holds a pre-doctoral fellowship from the FICYT. R. González Quirós held a contract funded by above project.

\section{REFERENCE}

Conway, D.V.P. - 1980. The food of larval blue whiting, Micromesistius potassou (Risso), in the Rockall area. J. Fish Biol., 16: 709-723.

Conway, D.V.P., S.H. Coombs, M.L. Fernández de Puelles and P.R.G. Tranter. - 1991. Feeding of larval sprat (Sprattus sprattus L.) and sardine (Sardina pilchardus Walbaum). ICES. C.M. 1991/L, 76

Conway, D.V.P., S.H. Coombs, M.L. Fernández de Puelles and P.R.G. Tranter. - 1994. Feeding of larval sardine, Sardina pilchardus (Walbaum), off the north coast of Spain. Bol. Inst. Esp. Oceanog., 10: 165-175.

Crawley, M. J. - 1993. GLIM for Ecologists. Blackwell, Oxford.

Cushing, D.H. - 1975. Marine ecology and fisheries. Cambridge 
University Press, Cambridge.

Dekhnik, T.V. - 1974. Comments on the articles by V.Ye. Zaika and N.A. Ostrovskaya entitled "Indicators of the availability of food to larval fish". J. Icthiol. Engl. Trans. Vopr. Ikhtiol., 14: 804-808.

Figerola, J., A.J. Green and L. Santamaría. - 2002. Comparative dispersal effectiveness of wideongrass seeds by waterfowl wintering in south-west Spain: quantitative and qualitative aspects. J. Ecol., 90: 989-1001.

González-Quirós, R. and R. Anadón. - 2001. Diet breadth variability in larval blue whiting as a response to plankton size structure. J. Fish Biol., 59: 1111-1125.

Hay, D.E. - 1981. Effects of capture and fixation on gut contents and body size of pacific herring larvae. Rapp. P.-v. Reun. Cons. Int. Explor. Mer., 178: 395-400.

Hjort, J. - 1914. Fluctuation in the great fisheries of northern Europe reviewed in the ligth of biological research. Rapp. P.-v. Reun. Cons. Perm. Int. Explor. Mer., 20: 1-228.

Houde, E.D. - 1987. Fish early life dynamics and recruitment variability. Am. Fish. Soc. Symp., 2: 17-29.

Last, J.M. - 1980. The food of twenty species of fish larvae in the west-central North Sea. Fish. Res. Tech. Rep., 60: 1-44.

Llanos, A., G. Herrrera and P. Bernal. - 1996. Análisis del tamaño de las presas en la dieta de las larvas de cuatro clupeiformes en un área costera de Chile central. Sci. Mar., 60: 435-442.

Munk, P. - 1997. Prey size spectra and prey availability of larval and small juvenile cod. J Fish Biol., 51(Suppl. A): 340-351.

Pearre, S. - 1986. Ratio-based trophic niche breadths of fish, the Sheldom spectrum, and the size-efficiency hypothesis. Mar. Ecol. Prog. Ser., 27: 299-314.

Pepin, P. and R.W. Penney. - 1997. Patterns of prey size and taxonomic composition in larval fish: are there general size-dependent models? J. Fish Biol., 51(Suppl. A): 84-100.

Porteiro, C. and G. Pestana. - 1997. Atlantic Iberian sardine (Sardina pilchardus Walb.) Working document to the GLOBEC/SPACC working group.

Sheldon, R.W., A. Prakash and W.H. Sutclffe. - 1972. The size distribution of particles in the ocean. Limnol. Oceanogr., 17: 327-340.

Shirota, A. - 1970. Studies on the mouth size of fish larvae. Bull. Jap. Soc. Sci. Fish., 36: 353-367.

Tudela, S., I. Palomera, and G. Quílez. - 2002. Feeding of anchovy Engraulis encrasicolus larvae in the north-west Mediterranean. J. Mar. Biol. Ass. UK, 82: 349-350.

Received June 27, 2002. Accepted November 24, 2004. 
